\title{
Albinism in US Charolais cattle
}

\author{
U. JAYASEKERA and H.W. LEIPOLD \\ Department of Pathology, College of Veterinary Medicine, \\ Kansas State University, Manhattan, Kansas 66506, U.S.A.
}

\begin{abstract}
Summary
Complete albinism occurred in 7 calves in two purebred Charolais herds. One calf exhibited nystagmus, opisthotonus and solar dermatitis. All calves had photophobia, acting blind in bright daylight. Two calves were necropsied. Irides, retina, skin and hooves contained scanty amounts or no pigment. Ganglionic layer of retina had a paucity of neurons. Inheritance of this defect is likely to be recessive.
\end{abstract}

\section{1. - Introduction}

Various types of partial or incomplete albinism have been reported in many breeds of cattle such as Holsteins, Guernseys and Aryshires (PETERSON et al., 1944), Herefords (LeIPold \& Huston, 1966), a Zebu breed (Roy, 1974), Swiss Simmentals (WEBer et al., 1973) and others as reviewed by LAUVERGNe (1968). Complete albinism has been documented only in one Guernsey male calf (LEIPOLD et al., 1968), one Austrian Murboden female (Schlegler, 1959), 4 Beef Shorthorns (GREene et al., 1973) and Brown Swiss calves (WinZenried \& Lauvergne, 1970).

Reported here is complete albinism in purebred Charolais calves.

\section{2. - Material and methods}

Defective calves for this investigation were part of a long-term study of congenital defects in cattle (LeIPOLD et al., 1972, LeIPOLD, 1978). Calves were observed clinically, were humanely euthanitized and necropsied immediately. Tissues were taken from brain, spinal cord, eyes, endocrine glands, internal organs and skin. Tissues were fixed in $10 \mathrm{p}$. cent buffered, neutral formalin, processed routinely, sectioned at 6 microns and stained with hematoxylin and eosin ( $\mathrm{H} \& \mathrm{E})$. 


\section{3. - Clinical history}

Complete albinism was reported from two purebred Charolais herds. The first calf brought to us was a 2-week-old purebred bull Charolais calf, and it was presented to us because of blindness. Six such blind calves were seen over a 5 year period in this purebred Kansas Charolais herd. They were sired by the same bull and all 5 dams were half sisters. One dam had an albino calf in successive years. After removal of the bull no more cases of albinism were observed. Bull and all dams involved had normal eye color.

A 5-week-old male purebred Charolais calf from a 50 head purebred cow Charolais herd in Missouri was presented to us in lateral recumbency. It had opisthotonus, nystagmus, and appeared to be blind. The owner had not encountered any other animal with pigmentary anomalies previously. The animal was euthanatized and necropsied.
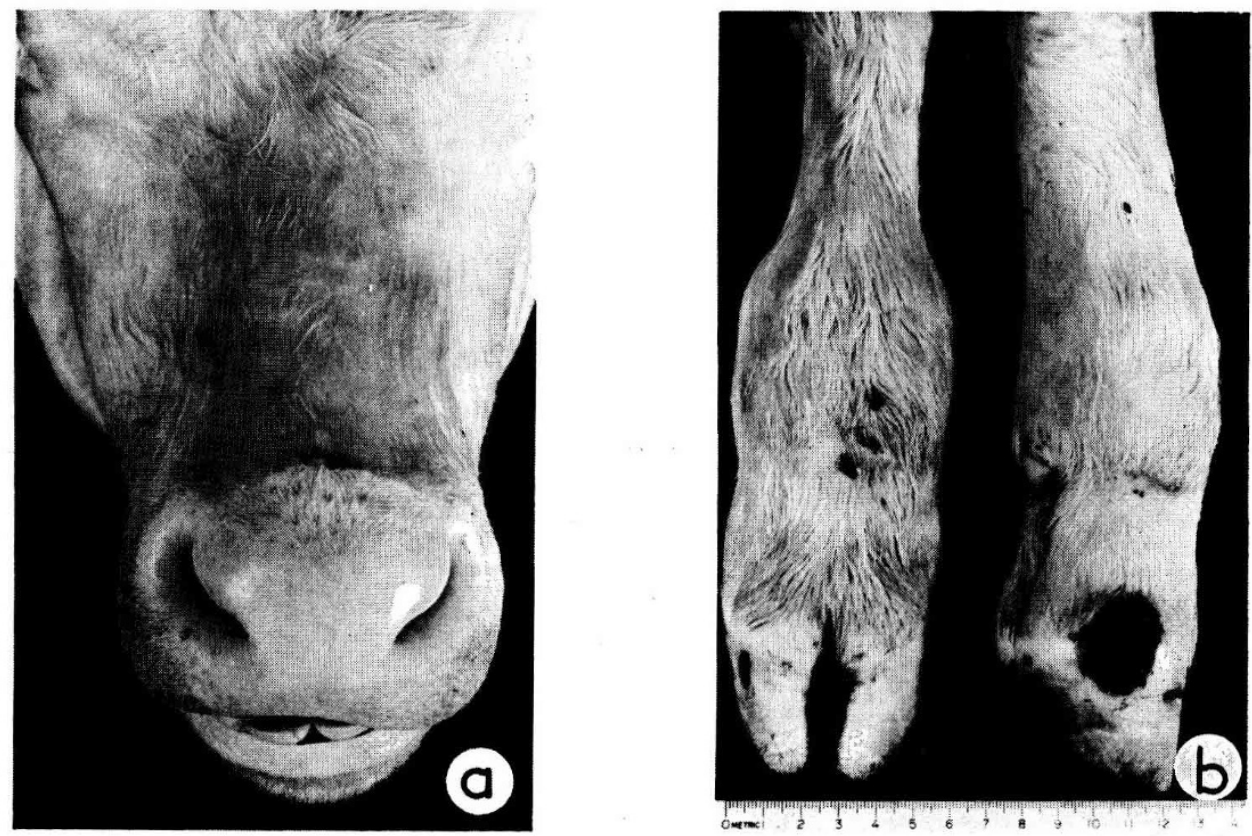

FIG. 1 a

Facial skin of a purebred Charolais calf affected with complete albinism Peau de la face d'un veau Charolais de race pure affecté d'albinisme complet

FIG. 1 b

Legs of a purebred Charolais calf affected with complete albinism Pattes d'un veau Charolais de race pure affecté d'albinisme complet 


\section{4. - Gross pathologic changes}

Both calves necropsied had skin which was whitish to pink and the hair was white and silky (fig. 1a and 1b). Areas around eyelids lacked pigment. The tongue was whitish-pink and hooves were yellowish-white. Skin over face, head and distal limbs revealed lesions of solar dermatitis and had a tendency to peel off (fig. $1 \mathrm{a}$ and $1 \mathrm{~b}$ ).

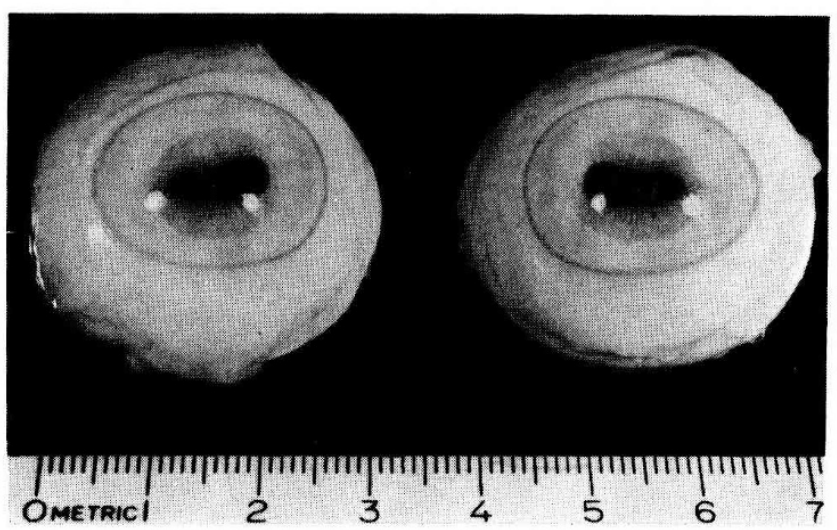

FIG. 2

Enucleated eyes of a purebred Charolais calf affected with complete albinism. Notice white iris color with a fainter center

Eil énuclée d'un veau Charolais de race pure affecté d'albinisme complet. Noter l'iris blanc, délavé au centre

The irides were faintly pink (fig. 2). Whitish conjunctiva were densely injected with blood. Ocular fundi were pink and vessels of the retina were prominent. In transverse sections, the tapetum nigrum and tapetum lucidum were indistinguishable and were pigmentless.

\section{5. - Histopathologic changes}

None of the layers of epidermis had melanin. Hairs were devoid of pigment. Epidermis was thin. Some sections of skin had mild infiltration of polymorphonuclear leukocytes in the dermis.

Retinal pigment layers did not contain pigment and scanty amounts were present in the ciliary body and limbus (fig. 3). Irides were completely free of pigment. A paucity of neurons was observed in the ganglionic layer of the retina. 


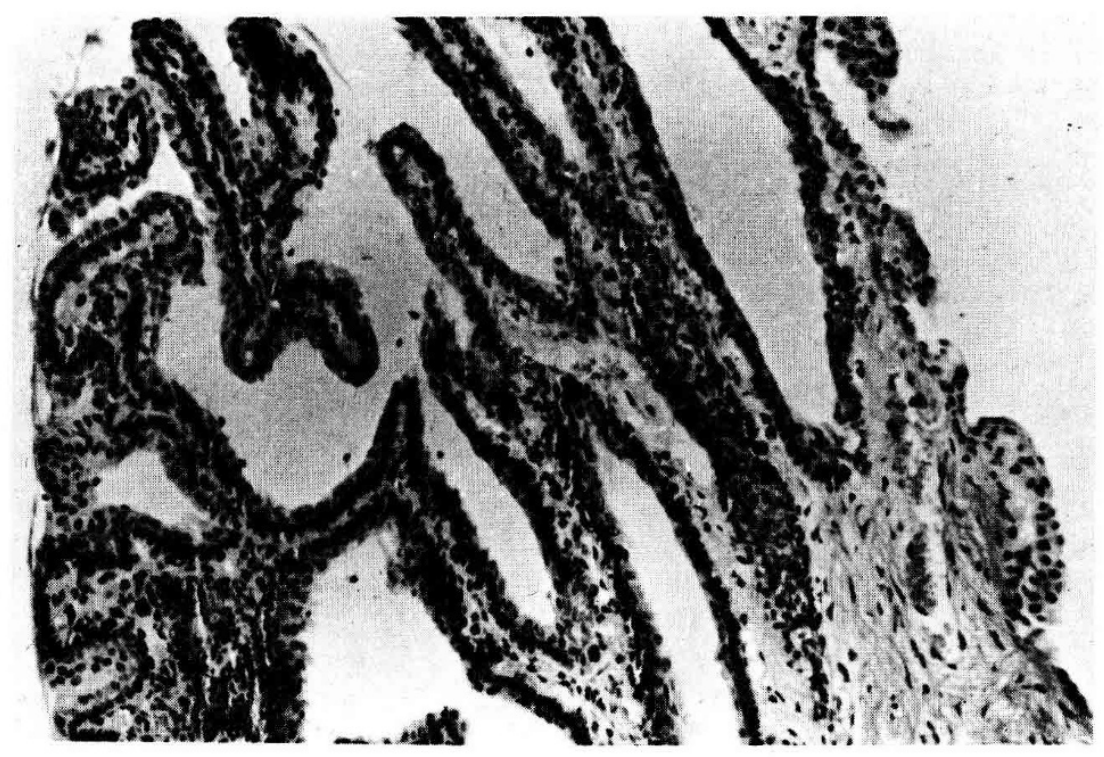

FIG. 3

Photomicrograph of ciliary body of a purebred Charolais calf affected with complete albinism. Notice complete lack of melanin granules. $H \& E, 120 X$

Microphoto des corps ciliaires d'un veau Charolais de race pure affecté d'albinisme complet. Noter l'absence totale de granules mélaniques. $H$ et $E, 120 X$

\section{6. - Discussion}

Coat color in animals is dependent on the amount of pigment in epidermis, depth at which it is located, and density of the medium between pigment and light scattering surface (Fox, 1953). Mammalian coat color is almost entirely dependent on presence or absence of melanin in the skin and hair, while eye color is determined by intraocular melanin and hemoglobin (SEARLE, 1968). In mammals, melanins exist in distinct forms as eumelanin (brown or black) and pheomelanin (yellow or reddish). Thus, the genetics of coat color in mammals is largely concerned with hereditary factors affecting these pigment granules by altering their number, shape, arrangement and position or by substituting one type of melanin to another (Fox \& Vevers, 1960). Eumelanin is derived from tyrosine and coverted to dopa (3.4dihydroxyphenylalanine) by catalytic action of the enzyme tyrosinase. DOPA is then oxidized to dopa quinone, undergoes further oxidation and polymerization to become melanin (HARRIS, 1959). Genes may act on any of the biochemical steps in the synthesis of melanin within the cell, and thus result in abnormal coat color (FITzPATRICK et al., 1958).

Clinical, opthalmologic and microscopic findings in the present case are consistent with complete albinism as elaborated by LAUVERGNe (1968), LeIPold et al. 
(1968), \& GreENE et al. (1973). Tapetal hypoplasia and optic disc colobomas as described by Gelatt et al. (1969) were not observed in these albinotic Charolais calves.

Albinism appears to be a rare defect. In Swiss Brown cattle in Switzerland, the recessive gene was estimated to house a frequency of 0.002 (WINZENRIED \& LAUVERGNE, 1970). In a US survey of bovine birth defects involving over 70,000 births, no albinos were encountered, making the frequency of the albino gene, if recessive, to be less than 0.004 (LEIPold et al., 1972). GreENE et al. (1973) concluded that the type of inheritance of albinism in Beef Shorthorns appeared to be recessive. The pattern of occurrence of albinism in these two purebred Charolais herds is suggestive of a recessive mode of inheritance. However, further investigations are warranted to elucidate the exact nature of inheritance of complete albinism among Charolais cattle.

\section{Résumé \\ Albinisme de bovins Charolais aux Etats-Unis}

Sept veaux complètement albinos sont apparus dans deux élevages de bovins Charolais en race pure aux Etats-Unis. Un des veaux présentait du nystagmus, de l'opisthotonus et une dermatite solaire. Deux veaux ont été disséqués. L'iris, la rétine, la peau et les sabots contenaient très peu, ou pas du tout, de pigment. La couche ganglionnaire de la rétine était pauvre en neurones. Le déterminisme héréditaire de cette anomalie est probablement récessif et la fréquence du gène dans la race assez basse.

\section{References}

FitzPatrick T.B., Brunet P. and Kukita A., 1958. The nature of hair pigment, In : The Biology of Hair Growth. Edited by Montagna W. and Ellis R.A., Academic Press, New York.

Fox D.L., 1953. Animal biochromes and structural colours. Cambridge University Press, Cambridge.

Fox H.M. and Vevers H.G., 1960. The nature of Animal Colours Sidgwick and Jackson, London.

Gelatt K.N., Huston K. and Leipold H.W., 1969. Ocular anomalies of incomplete albino cattle : opthalmic examination. Am. J. vet. Res., 30, 1313-1316.

Greene H.J., Leipold H.W., Gelatt K.M. and Huston K., 1973. Complete albinism in Beef Shorthorn calves. J. Hered., 64, 189-192.

Harris H., 1959. Human biochemical genetics. Cambridge University Press, Cambridge.

Lauvergne J.J., 1968. Catalogue des Anomalies héréditaires des Bovins (Bos taurus L.). Bull. tech. Dép. Génét. anim., 1 (I.N.R.A.).

Leipold H.W., Dennis S.M and Huston K., 1972. Congenital defects in cattle : Nature, cause and effect. Adv. Vet. Sci. Comp. Med., 16, 103-150.

Leipold H.W., Huston K., 1966. A herd of glass-eyed albino Hereford cattle. J. Hered., $57,179-182$. 
Leipold H.W., Huston K., Gelatt K.N., 1968. Complete albinism in a Guernsey calf. J. Hered., 59, 218-220.

Leipold H.W., 1978. Genetics and Disease. 11th Proc. American Assoc. Bovine Practitioner, 18-31.

Peterson W.E., Gilmore L.O. and Fitch J.B., 1944. Albinism in cattle. J. Hered., 35, 135-144.

Roy J.S., 1974. Observation on the albinism in a breeding bull in Uttarapradesch. Indian Vet. J., 51, 654-655.

Schlegler W., 1959. Auftreten eines Albinokalves bei der Murbodnerrasse. Wien. tierärztl. Mschr., 46, 196-199.

SEARle A.G., 1968. Comparative Genetics of Coat Colours in Mammals. Academic Press, New York.

Weber W., LAUVergne J.J., Winzenried H.W., 1973. Albinisme héréditaire en race Tachetée rouge de Suisse. Schweiz. Arch. Tierheilkd., 115, 142-144.

Winzenried H.U., Lauvergne J.J., 1970. Spontanes Auftreten von Albinos in der Schweitzerischer Braunviehrasse. Schweiz. Arch. Tierheilkd., 12, 581-587. 